\title{
GENRE FEATURES AND PLACE OF PSYCHOLOGICAL INTERNET-DISCOURSE IN DISCOURSE TYPOLOGY
}

Nowadays, it is not enough to place an advertisement online for individuals or companies, who want to popularise their services or goods. To meet clients' requirements and to become a well-known it is important to have an active profile in online services. The article provides theoretical material on the new type of discourse, which emerged in the past few decades and continues to develop, that is psychological Internet-discourse, which is becoming more and more popular nowadays due to the growing demand for psychological support and interest towards psychology as a science in particular. In the present paper, there is an attempt to define and corelate psychological Internet-discourse with the existing discourse types classifications and analyse its genre features. Also, some of the most popular definitions of such terms as "discourse" and "Internet-discourse" are provided in this article, and the lists of scholars who worked over the problem of defining these concepts are given. Psychological Internet-discourse is presented nowadays by blogs, vlogs, chats, personal and society websites created by psychologists and psychotherapists. This type was not investigated as a separate type of discourse, and there is a need to analyse its key linguistic features. Taking into account the most popular discourse classifications, such as classification by transmission channels and communication topics, it was defined that psychological Internet-discourse represents media discourse on psychological topics such as self-care, self-motivation, personal space and growth, self-awareness and presentation, stress and anxiety management, relationships and many others, aimed at supporting personal mental health and healthy environment in the society. Having analysed the genres presented by this type of discourse it should be mentioned that it is a complicated and multi-layered combination of different types of genres, such as informative, directive, communicative, presentational and others. The article provides explanations on how psychological Internet-discourse is related to the genres' classification, which was developed by L. Yu. Shchypicyna. The article also emphasises the practical value and future prospects of this study.

Key words: discourse, Internet-discourse, discourse typology, psychological Internet-discourse.

Анна НИПАДИМКА, orcid.org/0000-0003-1894-3456 викладач кафедри англійської мови технічного спрямування № 2 Національного технічного університету Украӥни «Київський політехнічний інститут імені Ігоря Сікорського» (Київ, Україна) a.nypadymka@gmail.com

\section{ЖАНРОВІ ОСОБЛИВОСТІ ТА МІСЦЕ ПСИХОЛОГІЧНОГО ІНТЕРНЕТ-ДИСКУРСУ У ТИПОЛОГІї ДИСКУРСУ}

У наш час не достатньо розмістити рекламу в Інтернеті для приватних осіб чи компаній, які хочуть популяризувати свої послуги або товари. Щоб задовольнити вимоги клієнтів та стати відомими, важливо мати активний профіль в Інтернет-сервісах. У статті наведено теоретичний матеріал про психологічний Інтернетдискурс, тобто новий тип дискурсу, щзо з'явився в останні кілька десятиліть, активно розвивається і стрімко набуває дедалі більшої популярності в наш час через зростаючий попит на психологічну підтримку та інтерес до психологї як науки зокрема. У иій роботі зроблено спробу визначити та співвіднести психологічний Інтернет-дискурс із наявними класифікаціями типів дискурсу та проаналізувати його жанрові особливості. Також у цій статті подано деякі найпопулярніші визначення таких термінів, як «дискурс» та «Інтернет-дискурс», а також наведено списки науковців, які працювали над проблемою визначення ичих понять. Психологічний Інтернет-дискурс нині представлений блогами, відеоблогами, чатами, персональними та суспільними вебсайтами, створеними психологами та психотерапевтами. Цей тип не досліджувався як окремий тип дискурсу, іє потреба проаналізувати його ключові лінгвістичні особливості. Беручи до уваги найпопулярніші класифікації дискурсу, такі як класифікація за каналами передачі та теми спілкування, було визначено, щзо психологічний Інтернет-дискурс представляє медіадискурс на такі психологічні теми, як турбота про своє здоров'я, самомотивація, особистий простір та розвиток, самообізнаність та презентація, методи подолання стресу та тривоги, стосунки з іншими людьми та багато інших, спрямованих на підтримку особистого психічного здоров'я та здорового 
середовища в суспільстві. Проаналізувавши жанри, представлені ции типом дискурсу, слід зазначити, щьо це складна і багатошарова комбінація різних типів жанрів, таких як інформативний, директивний, комунікативний, презентаиійний та інші. У статті подано пояснення того, як психологічний Інтернет-дискурс пов 'язаний із жанровою класифікацією, розробленою Л. Ю. Щипіциною. Також у статті наголошено на практичній ичінності та подальших перспективах изього дослідження.

Ключові слова: дискурс, Інтернет-дискурс, типологія дискурсу, психологічний Інтернет-дискурс.

The problem statement. For the past decade the Internet has become a powerful tool of representing psychologists, their practice, books, seminars, webinars etc. Nowadays it is not enough to place an advertisement online, due to the high competition of numerous specialists. This is one of the reasons for psychologists to create their posts and make publications on popular social networking websites. Therefore, this trend formed a completely new type of discourse, that is psychological Internet-discourse, which in its turn outlined the necessity to further investigation of this particular discourse type.

Objective of the present paper. The aim of this article is to clarify such terms as discourse, Internet-discourse and psychological Internet-discourse, to outline the role and place of psychological Internet-discourse in discourse typology, to analyse genre features of the investigated type of discourse.

Research review. The question of defying discourse itself, its typology is one the most important issues in linguistics nowadays. Such scholars as N. D. Artyunova, A. A. Barkovych, V. H. Borbot'ko, G. Brown, Yu. Ye. Davydenko, Teun A. van Dijk, M. Halliday, A. Z. Harris, V. I. Karasyk, V. A. Kox, O. S. Kubryakova, M. L. Makarovym, S. Mills, V. O. Pavlucka, H. H. Pochepcov, D. Schiffrin, P. Seryo, A. V. Shuhayev, Yu. S. Stepanov, M. Stubbs, V. Yu. Tyutyunnyk, G. K. Yule, and many others worked on shaping the definition of the term "discourse". Moreover, numerous scholars classified different types of discourse. Here, we can name such researchers as T. Byelova, B. El'son, J. Habermasa, V. Henks, V. Karasyk, D. Kristal, G. Kuk, O. I. Morozova, V. Piket, H. H. Pochepcov, I. S. Shevchenko, O. Strashevska. These scholars and many others made great contributions in the development of discourse typology. Nevertheless, psychological Internet-discourse was not investigated before, for the reason that this type of discourse is new, it emerged in the last decade.

Presentation of the main material. The term "discourse" has its origins in medieval Latin (about the end of the fourteenth century). According to the etymological dictionary, "discourse" in French sounds like "discours", which means "process of understanding, reasoning, thought", and in Latin as "discurrere", meaning "running around, back and forth" (Etymological dictionary). This term began to acquire more modern meanings only in the middle of the twentieth century, thanks to the American linguist Zellig Harris, who highlighted the importance of the concept of discourse for the development of functionalism in linguistics (Harris, 1952: 1-30).

Today, the concept of "discourse" is one of the central notions in linguistics. In his article, A. A. Barkovich notes that as a term, discourse has long been an innovation of linguistics, but at the same time interpretations of the concept of discourse exist more than for the vast majority of linguistic terms, which indicates the activity of the process of concept formation and its importance (Barkovich, 2015: 171).

The increased attention of scientists to this phenomenon is also evidenced by the presence of a large number of publications that directly or indirectly relate to discourse.

In Discourse as Structure and Process, Professor Teun A. van Dijk notes that it would be good if we could compress everything we knew about discourse into a convenient definition. But this is difficult to achieve, because discourse is a concept behind a complex phenomenon (Teun A. van Dijk, 1997).

It is important to consider some of the most common interpretations of discourse as the concept. According to the Collins Dictionary, discourse in linguistics is a natural spoken or written language in context, especially when the full text is taken into account (Collins Dictionary).

Researchers of this phenomenon went beyond just the text considered in context, and gave this concept a more thorough interpretation. G. Brown and G. Yule wrote that discourse analysis is an investigation of language in use, and it cannot be limited to the description of linguistic forms independent of the purposes and functions for which they were created (Brown G., Yule G., 1983).

Such scholars as F. Bacevich, Y. Davydenko, and V. Tyutyunnik consider discourse as a type of communicative activity, an interactive phenomenon, a speech flow that has different forms of manifestation (oral, written, para-lingual) (Bacevich, 2004; Davydenko, Tyutyunnik, 2016). A similar definition of the term "discourse" is given by N. D. Artyunova, who wrote that it is "a coherent text in combination with extralinguistic, pragmatic, socio-cultural, psychological and other factors; as a purposeful social activity" (Artyunova, 1990: 136). 
As much attention of linguists is paid to creating discourse typology, nowadays there are a lot of different classifications, based on various criteria. The most widespread is classification according to transmission media (Bacevich, 2004; Teun A. van Dijk, 1997).

F. S. Bacevich writes that discourse takes place within a specific channel of communication (Bacevich, 2004). I. G. Miroshnychenko, who studies mass media discourse, writes that transmission channels are media that can be divided into print (press discourse), television (radio discourse). With the development of the Internet the new channel of information transmission appeared, which has become a space for the formation of Internet discourse, and today in a separate group can be allocated a computer-mediated channel, which includes all electronic forms of information, and this is Internet-discourse (Miroshnichenko, 2011: 227). Moreover, the scholar mentioned above admits that Internet-discourse is a kind of media discourse.

Internet-discourse has become a special phenomenon that attracts the attention of numerous scholars. Issues of modern Internet-discourse are considered by such specialists as N. G. Asmus, N. A. Akhrenova, A. A. Barkovich , N. O. Hudz, I. B. Karpa, E. S. Kubryakova, N. Shkvorchenko, A. V. Shugaev, L. Yu. Shchipitsina, O. V. Lutovinova, A. A. Ushakov, I. G. Sidorova, E. Yu. Raspopina and others. The definition of the term Internet-discourse is still being shaped, due to the fact that it is a complex and multi-layered type of discourse that currently has many interpretations. A. A. Barkovich writes that Internet discourse is a speech activity in the field of computer-mediated communication, which is caused by the format of the Internet (Barkovich, 2015: 172). N. O. Hudz considers Internet-discourse as communication in the Global Network, a kind of network discourse, which in addition to communication on the Internet also includes communication in other nets, in particular, local networks (Hudz, 2019). Natalia Shkvorchenko believes that Internet-discourse is a process of creating a text in combination with pragmatic, socio-cultural, psychological factors, which includes the interaction of people and the mechanisms of their conscious cognitive processes (Shkvorchenko, 2019). E. Yu. Raspopina wrote that Internet-discourse is a complex text system due to extralinguistic socio-cultural factors and the specific situation of entering into speech contact with a computer and other electronic devices as users of each other on the Internet and users with discursive Internet space (Raspopina, 2012: 3).

In our study, Internet-discourse is considered as a kind of mass media discourse, represented by an array of posts or publications on the World Wide Web, cre- ated using audio-visual means, i.e. multimodal texts that combine verbal and non-verbal communication tools such as facial expressions, gestures, music, use of colours, graphic design, etc.

In addition to the typology by transmission channels, it should also be noted that the discourse can be classified by communication areas (political, legal, advertising, religious, etc.), by functional styles (official, domestic, scientific, artistic, journalistic).

Psychological Internet-discourse is represented by publications on such topics as psychology, personal development, people relationships, self-awareness etc. According to the functional style, psychological Internet-discourse is represented in the Global Network by numerous publications in social media and on the websites by professional psychologists, and we can say that it belongs to scientific-journalistic style.

Focusing on the discursive approach to the classification of genres of Internet-discourse, L. Yu. Shchypitsyna offers the following types: personal, political, legal, business, advertising, media, pedagogical. The researcher also divides Internet-discourse into genres depending on their communicative and functional features. Here she mentioned informative, directive, communicative, presentational, aesthetic, and entertaining genres (Shchypicyna, 2011).

Psychological Internet-discourse is a complex combination of different types of genres. It has the characteristics of a personal genre, which includes social networks, forums, chats, etc., as psychologists publish posts on social networks, create interactive chats to discuss certain publications. Taking into consideration that psychologists sell their information services, seminars, and books through the network, we can also trace the signs of business discourse, which includes posts aimed at doing business. Also, recently, psychologists have started to use context advertising, i.e., psychological Internet-discourse can also be classified as an advertising genre of discourse. Since the pragmatic goal of psychologists-bloggers is not only to sell services and products, but also to popularize psychology as a science, provide people with informational assistance, give consultations, etc., this type of discourse can also be attributed to pedagogical, which usually includes educational forums, online conferences and webinars.

Regarding the division of Internet-discourse genres according to the communicative functions of virtual communication, made by L. Yu. Shchypitsyna, there are the following ones: informative, directive, communicative, presentational, aesthetic and entertainment. Psychological Internet-discourse combines features from all these six genres. 
Taking into account the fact that psychologists provide people with information and share ideas, this type of discourse can be related to informative genre, although, typically, the informative genre is represented by encyclopaedias, dictionaries, reference books, etc. The investigated discourse has the features of directive genre, which task is to influence people in order to achieve a particular pragmatic goal. Considering the communicative genre, which is represented by social media, chats, and on-line conferences, we can also admit that psychological Internet-discourse fully complies with all these features. Moreover, psychologists via social media meet people's communicative needs and requirements. Furthermore, they represent themselves, their skills, achievements, and knowledge via personal web-sites, social media accounts and chats, thus this type of discourse is related to the presentational genre. Also, psychologists realise their creative potential and try to influence people aesthetically using multimodal, extralinguistic tools, and these comply with the aesthetic genre. The entertainment genre has the purpose to create the atmos- phere of interactive communication via different games. Psychological Internet-discourse has some fun elements, for instance specialists post memes and funny videos which make psychologists' newsfeed more appealing to the audience and less formal.

Conclusions. Thus, psychological Internet-discourse can be defined as a type of media discourse, which combines verbal (such as texts, sentences in some comments in chats, etc.) and non-verbal (para-linguistic) linguistic elements (such as graphic design, body language, music etc.). This type of discourse is represented by Internet resources and created by psychologist with particular pragmatic objectives, such as selling services and books online, presenting their skills and achievement, providing informational support on psychological issues to people, making psychology popular. All these factors influence the genre and linguistic features of psychological type of discourse and form a demand to conduct further investigations of it, with the perspective to create the set of verbal and non-verbal tools, which can be used in future by specialists in order to achieve their pragmatic goals.

\section{BIBLIOGRAPHY}

1. Арутюнова Н. Д. Дискурс. Языкознание: Большой энциклопедический словарь. Сов. энцикл., 1990. С. $136-137$.

2. Баркович A. A. Internet Discourse: Metalanguage Models of Practice. Весник Волгоградского государственного университета. 2015. Т. 14, вип. 5, С. 171-183. https://doi.org/10.15688/jvolsu2.2015.5.21

3. Бацевич Ф. С. Основи комунікативної лінгвістики. Київ : Академія, 2004. 344 с.

4. Гудзь Н. О. Інтернет-дискурс: структурна специфіка та конститутивні ознаки. Житомир : Житомирський державний університет імені Івана Франка. 2019. URL: http://eprints.zu.edu.ua/16727/1/\%D0\%93\%D1\%83\%D0\%B4\%D0 $\%$ B7\%D1\%8C.pdf

5. Давиденко Ю. Є., Тютюнник В. Ю. Сучасний Інтеренет-дискурс: особливості функціонування. Мови професійної комунікації: лінгвокультурний, когнітивно-дискурсивний, перекладознавчий та методичний аспекти : матеріали III-ї Міжнародної науково-практичної конференції. НТУУ «КПІ». Київ : Кафедра. 2016. С. 37-39.

6. Мірошниченко I. Г. Сучасні підходи до типології мас-медійного дискурсу. Сучасний мас-медійний простір: реалії та перспективи розвитку : матеріали II Всеукраїнської наук.-практ. конф. Вінниця : Вінниц. держ. педагог. ун-т ім. М. Коцюбинського. 2016. С. 227-231.

7. Распопина Е. Ю. Стратегический аспект информационного жанра интернет-дискурса : автореф. дис. ... канд. филол. наук : 10.02.19 «Теория языка». Иркутск. 2012. 21 с.

8. Шкворченко Н. Інтернет-дискурс як лінвістична категорія. Актуальні питання гуманітарних наук. Мовознавство. Літературознавство. 2019. Вип 23, том 3. С. 62-67.

9. Щипицина Л. Ю. Комплексная лингвистическая характеристика компьютерно-опосредованной коммуникации (на материале немецкого языка) : автореф. ... докт. филол. наук : 10.02.04 «Германские языки». Воронеж. 2011.40 с.

10. Brown G., Yule G. Discourse Analysis. Cambridge: Cambridge Univ. Press, 1983. Pp. 7-14.

11. Discourse. Collins Dictionary. URL: https://www.collinsdictionary.com/dictionary/english/discourse

12. Discourse. Online etymology dictionary (Douglas Harper ed.). URL: https://www.etymonline.com/word/discourse

13. Harris Z. Discourse analysis. Language. 1952. Vol. 28, № 1. P. 1-30

14. Teun A. van Dijk. The study of discourse. Discourse as structure and process. Discourse studies: A multidisciplinary introduction. London : SAGE Publications, 1997. Vol. 1, pp. 2-7.

\section{REFERENCES}

1. Arutyunova N. D. Dyskurs. [Discourse]. Yazykoznanye: Bolshoj encyklopedycheskyj slovar. Sov. encykl., 1990. pp. 136-137. [in Russian]

2. Bacevych F. S. Osnovy komunikatyvnoyi linhvistyky. [Communicative linguistics basics]. K.: Akademiya, 2004.344 p. [in Ukrainian].

3. Barkovich A. Internet Discourse: Metalanguage Models of Practice. Vestnik Volgogradskogo Gosudarstvennogo Universiteta. Serija 2. Jazykoznanije, 5. 2015. pp. 171-183. https://doi.org/10.15688/jvolsu2.2015.5.21.

4. Brown G., Yule G. Discourse Analysis. Cambridge: Cambridge Univ. Press, 1983. pp. 7-14. 
5. Davydenko Yu. Ye., Tyutyunnyk V. Yu. Suchasnyj Interenet-dyskurs: osoblyvosti funkcionuvannya. [Contemporary Internet-discourse: functional features]. Movy profesijnoyi komunikaciyi: linhvokulturnyj, kohnityvno-dyskursyvnyj, perekladoznavchyj ta metodychnyj aspekty: materialy III-oi Mizhnarodnoyi naukovo-praktychnoyi konferenciyi. NTUU «KPI». K.: Kafedra. 2016. pp. 37-39. [in Ukrainian]

6. Discourse. Collins Dictionary. URL: https://www.collinsdictionary.com/dictionary/english/discourse.

7. Discourse. Online etymology dictionary (Douglas Harper ed.). URL: https://www.etymonline.com/word/discourse.

8. Harris Z. Discourse analysis. Language. 1952. Vol. 28, № 1. Pp. 1-30.

9. Hudz N. O. Internet-dyskurs: strukturna specyfika ta konstytutyvni oznaky. [Internet-discoutse: structural specifics and constitute features] Zhytomyrskyj derzhavnyj universytet imeni Ivana Franka. 2019. URL: http://eprints.zu.edu.ua/16727/1/ $\% \mathrm{D} 0 \% 93 \% \mathrm{D} 1 \% 83 \% \mathrm{D} 0 \% \mathrm{~B} 4 \% \mathrm{D} 0 \% \mathrm{~B} 7 \% \mathrm{D} 1 \% 8 \mathrm{C}$.pdf [in Ukrainian].

10. Miroshnychenko I. H. Suchasni pidxody do typolohiyi mas-medijnoho dyskursu. [Modern approaches to mass media discourse typology]. Suchasnyj mas-medijnyj prostir: realiyi ta perspektyvy rozvytku: materialy II Vseukrayinskoyi nauk.prakt. konf., Vinnycya: Vinnyc. derzh. pedahoh. un-t im. M. Kocyubynskoho. 2016. Pp. 227-231. [in Ukrainian].

11. Raspopyna E. Yu. Stratehycheskyj aspekt ynformacyonnoho zhanra ynternetdyskursa [Strategic aspect of Internet-discourse informational genre]: avtoref. dys. ... kand. fylol. Nauk : 10.02 .19 "Teoryya yazyka". Yrkutsk. 2012. P. 21. [in Russian]

12. Shchypycyna L. Yu. Kompleksnaya lynhvystycheskaya harakterystyka kompyuterno-oposredovannoj kommunykacyy (na materyale nemeckoho yazyka)[Complex linguistic characteristic of computer-mediated communication (based on German language material)]: avtoref. ... doktora fylolohycheskyh nauk: 10.02.04 «Hermanskye yazyky». Voronezh. 2011. Pp. 12-38. [in Russian]

13. Shkvorchenko N. Internet-dyskurs yak linvistychna katehoriya [Internet-discourse as a linguistic category]. Aktualni pytannya humanitarnyh nauk. Movoznavstvo. Literaturoznavstvo. Drohobych. 2019. Issue 23, Vol. 3, pp. 62-67.[in Ukrainian]

14. Teun A. van Dijk. The study of discourse. Discourse as structure and process. Discourse studies: A multidisciplinary introduction. London: SAGE Publications, 1997. Vol. 1, 253 p. 